\title{
A regionális ökoszisztéma és az egyetemek szerepe az innovációs folyamatban
}

Napjainkban egy adott régió „okos” jellege az arra való képességével függ össze, hogy az emberi, strukturális és kapcsolati tôkéjét hogyan képes kiaknázni és a sokféle szereplôt hogyan képes a régió innovációs gyakorlatába integrálni. A folyamatban

alapvetố fontosságú, a regionális erôsségek és kapacitások intelligens szakosodást támogató kutatási és innovációs stratégiák európai programjával összefüggésben való kiaknázása, amelyben

kiemelten fontos az egyetemek közremúködése. Az egyetemek számos országban egyre aktívabb szerepet vállalnak a regionális fejlesztésben: az egyetemek, az ipar, a hatóságok és a polgárok a regionális innovációs ökoszisztéma legfontosabb szereplói. Ezen szereplók érintkezési felületén az innováció fontos elómozditóivá olyan koncepciók váltak, mint a közös tudástermelés, a szinergikus lehetôségek kihasználása és a kapacitásépités. Az egyetemeknek a civil társadalommal együttmúködve fontos feladata a hosszú távú szemlélet képviselete a politikai és piaci ciklusokon, ez adja meg egy további fontos feladatát, a stabilizáló szerepét.

\section{Bevezetés}

) elen cikkben amellett érvelünk, hogy az okos és hatékony regionális innovációs ökoszisztémák fenntartásában alapvető fontosságú az egyetemek új „harmadik szerepe”, a közös tudásteremtés. Elemezzük, hogy az egyetemek hogyan tudják és kezdik el betölteni ezt a szerepüket a regionális innovációs ökoszisztémákban, amellyel az okos régiókat okosabbá teszik, a különféle regionális szereplöket pedig támogatják abban, hogy hatékonyan müködjenek együtt. Cikkünkben bemutatjuk, hogyan müködik ez a folyamat a gyakorlatban, középpontba állítva az egyetemek hozzájárulását az okos régiókhoz.

A célzott változások erős alapja a legjobb gyakorlatok együttmüködésére épülhet: alulról felfelé kísérletezés, gyors prototípusok készítése és konceptualizálása, amikhez társadalmi innovációra van szükség. A tudásalapú társadalom megteremtéséhez és a megosztott tudásmenedzsmenthez új gondolkodásmódokra, a folyamat és különösen a végrehajtás szakaszában szoros együttmüködésre és hatékony eszköztárra van szükség. Az intelligens regionális fejlesztés kedvező feltételeinek megteremtése számos gyakorlatot támogat, amelyek beágyazódhatnak az európai gyakorlatokba. Ezen eszközök közül az alábbiakat emeljük ki: 
A tudomány és társadalom megvalósított párbeszéde a kutatókat párbeszédre ösztönzi a projektvezetőkkel, politikusokkal és egyéb döntéshozókkal. Ezen gyakorlati lánc lehetővé teszi a szakemberek számára annak megismerését, hogy a releváns kutatások hogyan befolyásolhatják a helyi és regionális kérdéseket, illetve a tudósok betekintést nyernek a városok és régiók napi müködésének gyakorlati kérdéseibe.

A tudás körkörös gazdaságának nevezett fogalom a fenntartható fejlődés új generációs koncepcióinak újfajta gondolkodását jelenti. Az egyetemi összehangolás ugyanis egy alapvetően új dimenzió az egyetemek vezetésében, amely hozzákapcsolódik az együttmüködés és a közös tudásalkotás új kultúrájának kialakításához. Mindez a regionális innovációs ökoszisztémán alapul, amelyben az egyetem az innováció és az átalakulás mozgatórugója.

A projektmegvalósítási eszközök között fontos szerep jut a tudás körkörös gazdaságának. E koncepció kapcsán a nemzeti és az európai finanszírozó szervek újra megvizsgálják és tanulmányozzák a már befejezett projektek eredményeit azért, hogy a releváns eredményeket új regionális és nemzeti kontextusban ismét felhasználhassák. Ezen hatékonyabb tudásmenedzsment segítségével a kutatási programok és a befejezett projektek eredményei (ötletek, ajánlások, módszerek, gyakorlati javaslatok, prototípusok és találmányok) újra felfedezhetők, újraértékelhetők és alkalmazhatók a jelenlegi programokban és projektekben is. Az ilyen gyakorlatok erősíthetik a vállalkozó egyetemek és a kormány szerepét az európai szintű együttműködés hatékonyságának növelésében.

Az eszköztár további elemét jelenti az Aalto Egyetem és a Párizsi Új Klub 2010-2014ben kifejlesztett Aalto Camp for Societal Innovation (továbbiakban: ACSI) koncepciója. Ez a társadalmi innováció globális platformjaként a kutatás, a tanulás és a gyors prototípuskészítés érdekében globális hálózatokat egyesít a társadalomban végbemenő rendszerszintű változások innovációs fejlesztése és a valós társadalmi kihívások miatt felmerülő új szükségletek kielégítése érdekében. Az ACSI meghatározza és egyértelmüvé teszi a Tudásháromszög modell módszertani és pedagógiai vetületét, erősíti és hasznosítja az egyetemen belül müködő különböző karok és egységek közötti együttmüködést, és a hálózati szervezet az egyetemek és a társadalom számára egyaránt lehetőségeket biztosító újfajta innovációs kultúrát támogat. Olyan munkamódszert segít kialakítani, amelyik egyszerre csökkenti a szervezeteken belüli határokat, és elösegíti rugalmas kapcsolatok kialakítását a társadalom többi szereplöjével. Az egyetem és a régiók által központilag szervezett, jellemzően 3-6 napos workshopok keretében több tudományterület 
nemzetközi szakértőinek részvételével oldanak meg valós regionális társadalmi problémákat és elemzik a gyakorlati fenntarthatóság követelményeit is. A Helsinki-Uusimaa Regionális Tanács számos más európai régióval és várossal együtt aktív szervező volt, mivel a nemzetközi együttmüködéssel növelni akarta a térség megújuló tudástőkéjét (EKA, 2014; Helsinki-Uusimaa Regional Council, 2014). Törekvésük sikerét és fenntarthatóságát jelzi, hogy 2019-ben az ACSI kezdeményezés már a második fejlesztési fázisát is elindította: ACSI 2.0 néven új egyetemi kurzus müködik az Aaltói Egyetemen (https://www.aalto.fi/center-for-knowledge-and-innovation-research-ckir/acsi-20). Az évek alatt összegyüjtött esettanulmányokat, jó gyakorlatokat és kutatási eredményeket a kutatócsoport több kiadványban is publikálta. Lappalainen és munkatársai (2015) kiadványukban a regionális ökoszisztéma fogalmainak magyarázata mellett egy-egy ország, köztük Magyarország gyakorlatát is bemutatták (Kálmán, Farkas és Dékány, 2015).

2010-ben a Budapesti Müszaki és Gazdaságtudományi Egyetem képviseletében kapcsolódtam be az Aaltói Egyetem koordinálásával müködő EUGENE munkacsoport tagjaként a regionális ökoszisztéma kutatásába. A kutatások Markku Markkula (az EU Régiók Bizottságának első alelnöke, majd elnöke; Espoo Város Önkormányzatának elnöke; Helsinki Régió elnöke) és Hank Kune (a Párizsi Új Klub alapítója) irányításával zajlottak. Tanulmányunk elsősorban ennek a kutatási időszaknak a tapasztalatait mutatja be.

\section{Tudásháromszög modell: tudásépítés, kapacitásteremtés}

Több európai közös nyilatkozat (pl. EUA, 2014) hangsúlyozza, hogy a felsőoktatási intézményeknek központi szerepük van egy olyan kultúra kialakításában, ahol a társadalmi és gazdasági fejlődésben a tudás központi és mérhető szerepet játszik. A megvalósítás kiindulási pontja a ma meghatározó nagy struktúrák szétbontása és egy együttmüködésen alapuló munkakultúra kialakulásának hatékony elősegítése lehet. A lehetséges müködési elvek közé sorolható együttmüködési modellek a Hármas Spirál és a Tudásháromszög modellje. A Hármas Spirál az egyetem-vállalkozás-közszféra közötti együttmüködésen alapszik. Ezt az évtizedek óta ismert és alkalmazott módszert egy további elem, az emberi tényező meghatározó szerepének hangsúlyozásával kell működőképessé tenni, mert az együttműködésre irányuló emberi viszonyrendszer

\section{A Tudásháromszög modell a} célok elérésének egyik eszközét jelentheti. A modell koncepciója kiemeli a kutatás, oktatás és innováció együttes támogatásának fontosságát, valamint a köztük lévó kapcsolat figyelemmel követését. Az egyetemi szereplók az innovációs hálózat középpontjában helyezkednek el, ahol a kiemelkedó képességek, az integráció és az irányítás magas foka elófeltételeit jelentik, amik hozzájárulnak Európa innovációs teljesítményének javitásához. A modell háromszög formájú ábrájával számos, többnyire olyan rendszerek leirásában találkozhatunk, amelyek célja az oktatás, kutatás és fejlesztés múködésének magyarázata (1. ábra). A koncepciót az Európai Bizottság vezette be (Lisszaboni Menetrend) Európa versenyképességének növelése céljából a 21. század elején (Lappalainen és Markkula, 2013). 
feltétele a hatékony térségi tudásmegosztásnak és innovációs képességnek. E modellek gyakorlati alkalmazása olyan regionális innovációs ökoszisztéma kialakulását segítheti, ahol az egyetemek a társadalmi változások mozgatói is. A Tudásháromszög együttmüködési modellnek (kutatás-oktatás-innováció) az egyetem különböző funkciói és szükségletei közötti szinergiát hangsúlyozva, a siker érdekében nagyobb teret kell nyernie.

A Tudásháromszög modell a célok elérésének egyik eszközét jelentheti. A modell koncepciója kiemeli a kutatás, oktatás és innováció együttes támogatásának fontosságát, valamint a köztük lévő kapcsolat figyelemmel követését. Az egyetemi szereplők az innovációs hálózat középpontjában helyezkednek el, ahol a kiemelkedő képességek, az integráció és az irányítás magas foka előfeltételeit jelentik, amik hozzájárulnak Európa innovációs teljesítményének javításához. A modell háromszög formájú ábrájával számos, többnyire olyan rendszerek leírásában találkozhatunk, amelyek célja az oktatás, kutatás és fejlesztés müködésének magyarázata (1. ábra). A koncepciót az Európai Bizottság vezette be (Lisszaboni Menetrend) Európa versenyképességének növelése céljából a 21. század elején (Lappalainen és Markkula, 2013). A háromszög mindhárom oldalához speciális platformokat és folyamatokat állít.

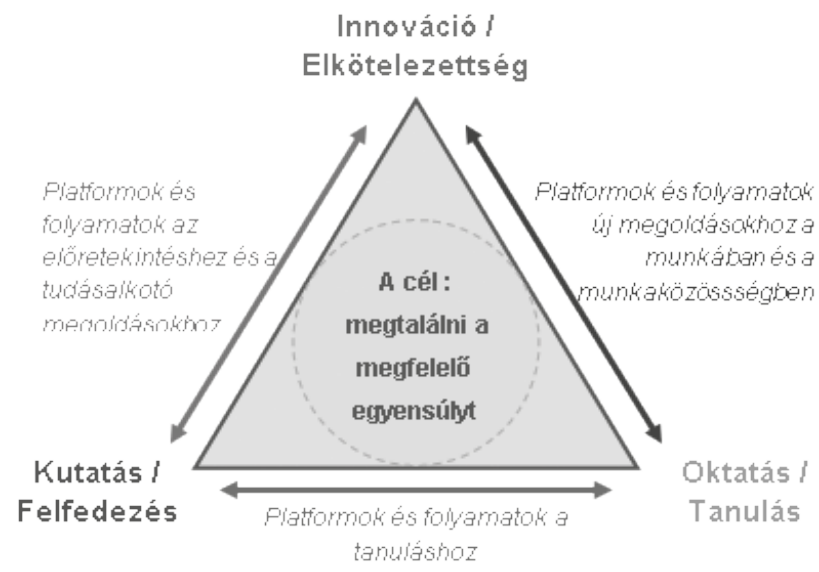

1. ábra. A Tudásháromszög modell alkotóelemei (Kálmán, 2014)

A Tudásháromszög modell célja a magán- és a közszféra szervezeteinek együttmüködése által az oktatás, a kutatás és az innováció közötti szinergia kialakítása és fenntartása, ami a résztvevők közötti kooperáción, kölcsönös megértésen és rendszeres kommunikáción alapszik. A modell megvalósításának folyamatában a hallgatók és a vállalatok szakemberei egymástól tanulnak, ami egy olyan tanulási környezetet kíván, ahol a felek szoros együttműködése révén valósulhat meg az együttes gondolkodás, az együtt tanulás és dolgozás, amit a kutatás, innováció és fejlesztés jellemez. A Tudásháromszög megvalósításában alapvető jelentőségü az elmélet és a gyakorlat egyesítése, amelyben javasolt módszerként a tevékenységek során való tanulás (learning by doing) és a fejlesztés folyamata során való tanulás (learning by developing) is szerepel, de emellett az egész életen át tartó tanulás is szerves része az oktatási környezetnek.

A Tudásháromszög modelljének három alappillére, a kutatás, az oktatás és a fejlesztés mint alapküldetések jelennek meg a modell bevezetésének és alkalmazásának, vagyis a sikeres megvalósításnak a folyamatában, amelyeknek más-más kulcsterületre kell fókuszálniuk (pl. a kutatás célja olyan elöremutató tudás alkotása, amelyet az oktatásban és az innovációban fel lehet használni). A kutatás, fejlesztés és innováció közötti szinergia megteremtése érdekében a társadalmi tevékenységeket különböző nézőpontból kell 
szemlélni és kialakítani. A Tudásháromszög megvalósításához a kutatás, az oktatás és a fejlesztés különböző koncepcióinak kialakításával együttesen alkotják meg a bevezetéshez szükséges platformokat és folyamatokat. A megvalósított modell a kívánt hatást és eredményt a tradicionális egyetemi menedzsment- és irányítási gyakorlatokon túl az elemek összehangolása révén érheti csak el. Az összehangolás egy alapvetően új dimenzió az egyetemek vezetésében, amely hozzákapcsolódik az együttmüködés és a közös tudásalkotás új kultúrájának kialakításához, ami a regionális innovációs ökoszisztémán alapul, ahol az innováció és átalakulás mozgatórugója maga az egyetem. Wallin (2006) szerint az összehangolás az erőforrások mobilizálásának és integrálásának képessége annak érdekében, hogy az ügyfél részére ajánlatot tegyen, és egyúttal értéket is teremtsen az ügyfélnek, az összehangolónak és a hálózat tagjainak. Az összehangoló figyelembe veszi azokat a feltételeket, amelyek alapján a párbeszéd kialakul, hogy meghatározhassa és megvalósíthassa a tervszerü erőforrás-elosztásokat, azzal a céllal, hogy ajánlatot nyújthasson az ügyfélnek.

A Tudásháromszög gyakorlati megvalósításában egyre fontosabbá válik a tömeges civil szerveződés és a kreativitás szerepe (ami gyakran érhetö tetten a négyes és az ötös spirál koncepciójának leírásában is), ebben az összefüggésben pedig a digitális média mint a tömeges önszerveződés platformja válik igazán hatékony elemévé az innovációs ökoszisztémának. A folyamatban érzékelhetô, hogy az új hálózati és szolgáltató infrastruktúrák fokozatosan átveszik a korábban használt internet és web helyét. A kihívások, amelyekkel az oktatás és a munka világa is szembenéz, egyszerre mentálisak és technológiaiak, azonban a meglévő technikai lehetőségeket a munka- és tanulási folyamataink során csak részlegesen használjuk. A legújabb digitális technológiák és szolgáltatások használatának optimális szintje sokkal magasabb annál, amit az emberi viselkedés alkalmaz és aktívan használ. Mivel Európában és föként Ázsiában a nemzetközi verseny egyre erőteljesebbé válik, szükségessé válnak az innovatív és akár radikális lépések is az elörejutáshoz (Markkula, 2013).

\section{A Tudásháromszög gyakorlati} megvalósításában egyre fontovezódés és a kreativitás szerepe

(ami gyakran érhetó tetten a négyes és az ötös spirál koncepciójának leirásában is), ebben az összefüggésben pedig a digi-

tális média mint a tömeges önszervezódés platformja válik igazán hatékony elemévé az innovációs ökoszisztémának.

A folyamatban érzékelhetó, hogy az új hálózati és szolgáltató infrastruktúrák fokozatosan átveszik a korábban hasz-

nált internet és web helyét.

A kihívások, amelyekkel az oktatás és a munka világa is szembenéz, egyszerre mentálisak és technológiaiak, azonban a meglévó technikai lehetôségeket a munka-és tanulási folyamataink során csak részlegesen használjuk. A legújabb digitális technológiák és szolgáltatások használatának optimális szintje sokkal magasabb annál, amit az emberi viselkedés alkalmaz és aktivan használ. Mivel Európában és fóként Ázsiában a nemzetközi verseny egyre eróteljesebbé válik, szükségessé válnak az innovatív és akár radikális lépések is az elórejutáshoz (Markkula, 2013). sabbá válik a tömeges civil szer- 
Az oktatás szerepe (egyetemeken és más felsőoktatási intézményekben) és a Tudásháromszög modelljének összefüggései az Európai Bizottság tíz évvel ezelőtti határozatában is megjelenik, miszerint, ha az Európai Unió fel akar készülni arra, hogy a versengő globális gazdaság, az éghajlatváltozás és az elöregedő lakosság okozta hosszú távú kihívásokkal szembenézzen, akkor a modell mindhárom elemének önmagában és egymással együtt is jól kell müködnie (Kálmán, 2014). A 2009-ben kiadott határozat arra biztatta az unió országait, hogy megfelelő összhangot alakítsanak ki az oktatás, kutatás és innováció területein, a már müködő pedagógiai reformokat felgyorsítsák, az egyetemek és az üzleti szféra között kapcsolatokat alakítsanak ki, illetve intézkedéseket tegyenek az egyetemi innovációs kultúra kialakítása érdekében. A határozat a minőségbiztosítás oldaláról is új megközelítési módokat igényel, vagyis a Tudásháromszög elveinek gyakorlati megvalósítása széles skálán érinti az egyetemi múködést (EUA Charta, 2008).

A bevezetés lehetőségével kapcsolatban az egyes országokban az oktatásban megvalósítható megújulási igényekről és lehetőségekről felméréseket végeztek és azokból jelentést készítettek, ami értékelte az Európa-szerte már megvalósult megújulási példákat és jó gyakorlatokat. A különböző egyetemektől kapott gazdag információhalmaz ötleteket és tanulságokat összegez, amelyek a modell és az oktatási tevékenységek integrálása érdekében az egyetemek és a döntéshozók hasznára válhatnak (EUA, 2014).

A Technológiai Jövőkutatási Intézet (amely része az EU Közös Kutatóközpontjának) elemezte azokat a tevékenységeket, amelyek hozzájárulnak az EU tudásgazdaságának megerösödéséhez, és ennek részeként megfogalmazta a Tudásháromszög igényét. A pontok összekötése címü jelentésük (Hervas és Mulatero, 2009) hangsúlyozza, hogy a szükséges intézkedéseket úgy kell megvalósítani, hogy ezek hatását egyidejűleg elemezzék a kutatás, oktatás és innováció szempontjaiból is. Ennek megvalósításához az intézkedések jól szervezett összehangolása szükséges annak érdekében, hogy motiválja az egyetemi alkalmazottak és érdekeltek széles körét az új Tudásháromszög koncepció kialakításában és azonnali megvalósításában. A javaslatok szerint az oktatás, kutatás és innováció területén szisztematikus és folyamatos együttmüködésre van szükség. Az együttműködési készség és képesség, illetve az ezt lehetővé tevő bizalom kialakítása és erősítése kulcsfontosságú, enélkül a technológia (transzformatív) potenciálja jórészt kihasználatlan marad. Az innováció kutatással valósulhat meg, amelynek köszönhetően a tudományos felfedezések kereskedelmi innovációvá válhatnak (alkalmazások révén). A modell a fordított kapcsolatra is jelentős hangsúlyt fektet, miszerint a kereskedelmi innováció a kutatás hatékonyságának növelésével befolyásolja a kutatási folyamatokat. A modell értelmezésében az oktatás túlmutat a kutatás, a fejlesztés $(\mathrm{K}+\mathrm{F})$ és az innováció bemeneti egységként való értelmezésén, az innováció pedig az oktatási és $\mathrm{K}+\mathrm{F}$ tevékenységek kimeneti eredményként való jelentésén.

A globális hálózati gazdaság számos tevékenységet vár el az egyetemektől, amelyek a hálózati müködés folyamataira és struktúrájára, valamint az ezek kialakításához és fenntartásához szükséges kompetenciák fejlesztésére fókuszálnak. A Tudásháromszög modelljének megvalósítása átalakítási lépéseket vár el az egyetemektől, segítségével azonban ezeket a lépéseket szisztematikusan tervezik és valósítják meg, a folyamat egyszerübbé válik, a tevékenységek nyereségessége és hatása pedig jelentősen megnő. Markkula (2013) szerint, ha az egyetemeken alkalmazzák a Tudásháromszög együttmüködési modellt (kutatás-oktatás-innováció), amely hangsúlyozza az egyetem különböző funkciója és szükséglete közötti szinergiát a siker érdekében, akkor ezek együtt meg tudják alkotni az utat a regionális innovációs ökoszisztéma felé, ahol az egyetemek a társadalmi változás mozgatói is egyben.

A magas minőségü egyetemeken az oktatási és innovációs tevékenységek erősen jövőorientáltak, ezért a kutatási folyamatokban az egyik legjelentősebb szerepe az előrelátásnak van. Az oktatás esetében a megfelelő tanítási és tanulási módszerek és 
az egész életen át tartó tanulás feltételeinek megteremtése jelent fontos sikertényezőt, az innováció esetében pedig a lehetséges fejlesztések tesztelése, a formátumok segítségével elkészített prototípusok, ahol a hallgatók is jelentős szereppel bírnak, és aktív résztvevői ezen folyamatoknak. A Tudásháromszög-kultúra a korábbinál erőteljesebb hangsúlyt fektet a stratégiai partnerségekre és szövetségekre. A siker előfeltétele, hogy minden szereplő a többi résztvevő számára szükséges értéket adhasson, ami megkívánja a folyamat egy vagy több részének megvalósításához szükséges magas szintü kompetenciákat az egyetemi közösségen belül. Az átalakulási folyamat legalapvetőbb elemei közé tartozik az egyetem stratégiai fókuszának a kiválasztott nagy társadalmi kihívásokra való ráirányítása és a Tudásháromszög fogalmának megfelelően az egységek müködési tevékenységeinek kidolgozása. Összességében a Tudásháromszögre mint széleskörű társadalmi innovációra kell tekinteni, amelyen keresztül Európa megerősítheti kutatási lehetőségeit, növelheti a tehetségek oktatásának képességét, valamint elősegíti és megteremti a keresletvezérelt nyílt innovációs platformok létrejöttét a társadalom széles rétegeinek használatára (CESAER, 2011).

Az együttmüködő platformok és a különböző felületek közötti müködés összehangolása az egyik legkritikusabb sikertényezője az egyetem-ipar-közigazgatás közötti együttmüködésnek. Mindehhez egy olyan fogalomra van szükség, amelyet számos olyan interaktív elem és folyamat együttese jellemez, mint ami a sikeres globális üzleti ökoszisztémákat. A regionális innovációs ökoszisztéma modellje a hálózati kultúrán alapul, ahol a nagyszámú együttmüködő szereplök különböző szerepekben és különböző felelősséggel müködnek. A Regionális Innovációs Ökoszisztémák (Regional Innovation Ecosystems, RIE) kialakításának célja megérteni és erősíteni az adott régió azon képességét, hogy gondozza az új innovációt és fokozza a versenyképességet. Az ökoszisztémák hajtómotorját az együttmüködési készség és az interdiszciplináris megközelítés adja (szemben a szervezetek hatékonyságát csökkentő információ- és ismeretmegosztás hiányával), ahol a hajtóerő szerepét az egyetemek látják el, a legfontosabb szereplők pedig azok a vállalatok, amelyek kereskedelmi forgalomba hozzák az innovációt. A Regionális Innovációs Ökoszisztémákba bekapcsolódó csoportok egyúttal kutatói, fejlesztői,
A Tudásháromszög-kultúra a korábbinál eróteljesebb hangsúlyt fektet a stratégiai partnerségekre és szövetségekre. A siker elófeltétele, hogy minden szerepló a többi résztvevó számára szükséges értéket adhasson, ami megkívánja a folyamat egy vagy több részének megvalósításához szükséges magas szintú kompetenciákat az egyetemi közösségen belül. Az átalakulási folyamat legalapvetóbb elemei közé tartozik az egyetem stratégiai fókuszának a kiválasztott nagy társadalmi kihívásokra való ráirányitása és a Tudásháromszög fogalmának megfelelóen az egységek múködési tevékenységeinek kidolgozása. Összességében a Tudásháromszögre mint széleskörú társadalmi innovációra kell tekinteni, amelyen keresztül Európa megerósítheti kutatási lehetôségeit, növelheti a tehetségek oktatásának képességét, valamint elósegíti és megteremti a keresletvezérelt nyilt innovációs platformok létrejöttét a társadalom széles rétegeinek használatára (CESAER, 2011). 
felhasználói és termelői hálózatok, amelyek mind szükségesek ahhoz, hogy gyorsan elöállítsák és a piacokra eljuttassák az új versenyképes termékeket, szolgáltatásokat és egyéb innovációkat. A Tudásháromszög modelljének gyakorlatban való alkalmazása megmutatja, hogy a regionális innovációs ökoszisztémák megteremtéséhez közös vízióra, a felfedezéseket és a vállalkozókedvet támogató kedvező légkörre, együttmüködésen alapuló tanulás és tudás megteremtésére, közös fogalmakra és mentális modellekre, továbbá a változásmenedzsment és összehangolás rendszerszerü kultúrájára és a digitalizáció optimalizált kihasználására van szükség, ahol a felhasználók mint innovátorok motiválása és elköteleződése hosszú távú változást eredményezhet (Markkula, 2011).

\section{Smart city: okos város, okos régió}

Napjainkban a digitális technológiának a mindennapi élet kibővítésére való felhasználásá során gyakran találkozunk az „okos” jelzővel (pl.: okostelefon, okosóra, okos város, okos régió). Az elnevezés gyakori, az azonban kevésbé tisztázott, hogy mit jelent és mire utal pontosan az „okos” jelző, ami gyakran elfedi azokat a valós kihívásokat, amelyekkel az okos eszközök, városok, régiók és azok használói vagy polgárai szembesülnek. A hétköznapi értelmezésben egyet jelent a digitalizált formával, vagy a digitális tartalmat biztosító szoftver fejlettségével és újdonságával, a digitális szolgáltatások sokszínüségével, vagyis a tartalom leggyakrabban az informatika köré szerveződik.

A bevezetésben megfogalmazottak szerint egy régió „okos” jellegét elsősorban az határozza meg, hogy milyen mértékben képes kiaknázni az emberi, a strukturális és a kapcsolati tőkéjét, és az innovációs gyakorlatba minél több szereplőt tudjon bevonni. A folyamatban az emberi bizalom és együttmüködés új strukturális tőkeként jelenik meg, melynek fontos befolyásoló ereje van a régió müködésére. Azonban az, hogy egyszerüen csak növelik egy területen a szoftverfejlesztők számát, vagy élénkítik az informatika köré szerveződő üzleti klaszterek tevékenységét, és a polgárok számára digitális szolgáltatásokat biztosítanak, nem elegendő ahhoz, hogy a régiót intelligensebbé, okosabbá tegye. A regionális ökoszisztéma aktív összehangolása olyan koncepciók által, mint a tudás közös megteremtése és kiaknázása, a lehetőségek feltárása és a kapacitásépítés, teszi az „okos régiót” még „okosabbá”! Az okos jelleget az növeli, ha a jól összehangolt regionális innovációs ökoszisztéma olyan eröteljes ,intelligens szakosodási stratégiával" párosul, amely kiaknázza az egyetemek által betöltött új társadalmi szerepeket, fogalmazza meg Markkula és Kune (2015). A folyamatban alapvető fontosságú, hogy a regionális erősségeket és kapacitásokat az intelligens szakosodást támogató kutatási és innovációs stratégiák európai programjával összefüggésben aknázzák ki, és mindebben az egyetemek a saját, különböző szerepeikben közreműködjenek. Az egyetemek fontos eszközök abban, hogy a tanulságokat kodifikálják, s a többi szereplőt segítsék abban, hogy a tanulást átvigyék a gyakorlat következő szintjére. Az egyetemek a regionális innovációs ökoszisztémákban kezdik ezt a szerepet betölteni, s ezzel az okos régiókat intelligensebbekké teszik, a különféle regionális szereplöket pedig támogatják abban, hogy hatékonyan müködjenek együtt (Markkula és Kune, 2013, 2015).

Az egyetemek számos országban (pl. Svédország, Finnország) egyre aktívabb szerepet vállalnak a regionális fejlesztésben. Az egyetemek, az ipar, a hatóságok és a polgárok érintkezési felületén az innováció fontos elömozdítóivá váltak a már említett közös tudástermelés, a tudás és a lehetőségek kiaknázása, valamint a kapacitásépítés megvalósítása által. Az említett esetek közül Finnország kiemelkedő lehetőségeket példáz, ahol kialakult és történelmileg is meghatározóvá vált a közös előnyök megtalálására épülö „konszenzuskultúra”, ami stabil és növekvő motivációt biztosít a közös akciókhoz, az eröforrások megosztásához és megsokszorozásához. 
Jelen tanulmányban amellett érvelünk, hogy az okos és hatékony regionális innovációs ökoszisztémák fenntartásában alapvető fontosságú az egyetemek új, harmadik, társadalmi szerepe.

\section{A régió mint innovációs központ}

A '90-es évek óta a városok és a régiók vizsgálták annak módjait, hogyan növelhetik az élet minőségét a technológia révén, és gyakorta buzgón felvették az „okos” címkét olyan célokra irányuló tevékenységek jelölésére, mint a hatékony városirányítás, a gazdasági fejlődés és a presztízs növelése. Ez az eszköz- és technológiaalapú megközelítés produkált néhány látványos eredményt, azonban kiindulópontját inkább a technológia és nem a városi élet kihívásai jelentik, vagyis nem használja ki, és nem szolgáltat kielégítő bizonyítékot arra nézve, hogy mi az, ami a való világ kihívásainak kezelésében igazán müködik, és a régió polgárait kevéssé vonja be (NESTA, 2015).

A tanulmányban az „okos” jelzőt Markkula és Kune (2015) szerint értelmezzük, ami a gondolkodási kapacitás és a technológia hatékony együttműködésében és kölcsönösségében jelenik meg egy adott régió életminőségének javítása céljából. Az okos polgárok szintjén az okos jelző a tudás megértésére és hatékony felhasználására való képességet jelenti, valamint a digitális médiának a mindennapi hétköznapokban való hatékony felhasználásának képességét. Mindez nem korlátozódik a technológia eszközeire, mert önmagában a hardver és a szoftver nem megoldás: a szó hagyományosabb értelmében az „okosság” az egyének, szervezetek és régiók azon képessége, hogy a tudást megértsék és feldolgozzák, új tudást termeljenek és azt a gyakorlatba átültessék. Az információs és kommunikációs technológiák támogatják az említett képességet, de elsősorban az egyéneken múlik, hogy ezen képességeiket hogyan tudják alkalmazni és az ehhez szükséges gondolkodási folyamatokat irányítani, illetve a gondolkodási készségeiket hatékonyan használni.

Az elsajátítás elősegítésére való alapképességük révén az egyetemek az említett megközelítés hatékonnyá tételében kulcsszerepet játszanak. A régiók felismerik, hogy az említett kihívások kezelésében növekszik az egyetemek szerepe és a tudományos kutatás fontossága, de annak kérdése, hogy a kutatási tudás hogyan ültethető át gyorsan és hatékonyan a gyakorlati alkalmazásokba, még mindig fontos probléma. A régió tanulási képessége, a szervezeti tanulás gyakorlata, valamint a kutatás és innováció multidimenzionális csapatokban és hálózatokban való lefolytatásának képessége a modern társadalmak alapvető követelménye. Ez része annak, ami a régiókat „okossá” teszi. Azonban a nagyobb regionális innovációs ökoszisztémákban mind a tanulás fontossága, mind nehézsége jelentősen növekszik (Lappalainen és mtsai, 2015).

A regionális innovációs ökoszisztéma - üzleti életből, a kormányszférából, az egyetemekről és a civil társadalomból származó - szereplőinek érintkezési felülete az, ahol a tudás feltárása és potenciális alkalmazása legerőteljesebben kiaknázható. A hatékony együttmüködés itt meghatározza, milyen okos lehet a régió, és potenciálja hogyan aknázható ki. Meghatározza a regionális innovációs ökoszisztéma minőségét és hatékonyságát, ami sok esetben nem könnyü feladat, és a társadalmi partnerek hatékony együttmüködése is gyakorta komoly kihívást jelent. Ennek kezelése érdekében az Európai Unió aktívan tanulmányozta és ismerte el az intelligens szakosodáson alapuló regionális kutatási és innovációs stratégiák koncepcióját - az úgynevezett intelligens szakosodást támogató kutatási és innovációs stratégiákat (Research and Innovation Strategies for Smart Specialisation, továbbiakban: RIS3). A RIS3 az innovációvezérelt növekedés számára regionális politikai keretet és alapot nyújt, a vállalkozói felfedezés folyamatának kell tekinteni: olyan interaktív és innovatív folyamatnak, amelyben az új tevékenységekre vonatkozó információt a piac erői és a magánszektor az egyetemekkel együtt fedezik fel 
és termelik, a kormány pedig összegzi az eredményeket, s a potenciál kiaknázására leginkább képes szereplőket hozza helyzetbe (Foray és mtsai, 2012; Goddard, 2009, 2011). A következő részben arra a kérdésre keressük a választ: Hogyan ültethető át ez a stratégia a gyakorlatba és kik a szereplök?

\section{Az innovációs ökoszisztéma jellemzői}

A nemzetközi versenyelöny a központi regionális szereplőknek azon a közös szándékán alapul, hogy a régiót jelentős innovációs központtá, illetve egyes kiválasztott témák vonatkozásában akár az innováció éllovasává tegyék (Launonen és Viitanen, 2011). Az Európai Unió költségvetésében 2021-től kulcsszerepet kap a szélesen értelmezett ökoszisztémában folyó innováció elősegítése és hasznosítása (Európai Bizottság, 2017). Minden olyan innovációs központnak, amely egyszersmind innovációs ökoszisztéma is, négy közös jellemzője van:

1. Globálisan értékelt szakértelemmel és az említett szakértelemre épülő vállalati tevékenységekkel rendelkeznek.

2. Olyan tudást termelnek, amelyet aztán globális léptékben alkalmaznak.

3. A központ nemzetközi szakértelmet, kompetenciavezérelt üzleti tevékenységeket és befektetéseket vonz.

4. Olyan kiemelkedő vállalatokkal rendelkeznek, amelyek helyileg és globálisan is müködnek.

A szervezeti céloknak és szükségleteknek az ökoszisztéma kontextusában való meghatározásához, valamint annak bemutatásához, hogy a kívánt minőség biztosításához mi szükséges, együttmüködési formákra van szükség, amelyekben meghatározott célok és kritériumok vezérlik a regionális szereplőket abban, hogy kompetenciájukat regionális projektekben használják. A vállalatoktól, egyetemektől és a társadalmi irányítók részéről megkívánt kompetencia általános szintjét minden egyes feladat esetében meg kell határozni. Ez az erőfeszítés a korábbi innovációs modellek modernizálását is megkívánja, amelyek a résztvevők közötti együttmüködések különböző formáit támogatják, hangsúlyozzák.

Az innovációs modellek közül esőként, a '90-es években alakult a Triple Helix (Hármas Spirál), ami három szereplöi csoport, az ipar, a kormány és a többi közszféra-szervezet, valamint az egyetemek együttmüködő közremüködésének szükségességét hangsúlyozza (Etzkowitz és Ranga, 2011). Ezt a Quadruple Helix (azaz a Négyes Spirál) negyedik szereplőként a média- és kultúraalapú nyilvánossággal egészíti ki, elsősorban a tudásalapú társadalom és demokrácia lehetőségét támogatja, ahol a tudásalapú gazdaság a tudásalapú társadalommal közösen fejlődik. A legszélesebb értelmezést viszont a Quintuple Helix (Ötös Spirál) innovációs modell adja, amely az előzőek mellett a társadalom természetes közegét is magában foglalja. A modell a társadalom és gazdaság 21. századi társadalmi-ökológiai változásának szükségességét hangsúlyozza, ennek értelmében a társadalom és gazdaság természetes környezetére is úgy tekint, mint a tudáselöállítás és innováció hajtóerejére, vagyis a tudásalapú gazdaság meghatározó lehetőségére.

Az Európai Bizottság 2009-ben a jövőbeni fejlődés fő kihívásaként határozta meg a társadalmi-ökológiai változást. Ebből kifolyólag támogatja az Ötös Spirál egy - csak győztes - kimenetellel rendelkező formáció létrejöttét az ökológia, tudás és innovációk között, csakúgy, mint a gazdaság, társadalom és demokrácia között létrejövő együttmüködés esetében (Carayannis, Barth és Campbell, 2012). Bár az utóbbi években a Négyes és az Ötös Spirál gondolata is gyakran felvetödött a viták során, számos országban a tényleges együttmüködés még kialakulóban van, és számos régióban még a Hármas Spirál típusú együttmüködést is nehéz elérni. 
A már müködő gyakorlatokra jelent példát Finnország, ahol a Triple Helix modell közös létrehozásának és hatékony kivitelezésének nagy hagyománya van, polgárai pedig aktívan vesznek részt a közszféra folyamataiban (Lappalainen és mtsai, 2015). A Hármas Spirál modernizálása azonban még Finnországban is újfajta lépést jelent: a regionális innovációs ökoszisztéma középpontba állítását, valamint az ökoszisztéma-gondolkodás annak megfontolására való felhasználását, hogy mely szereplői csoportok relevánsak a társadalmi változás folyamataiban. A megvalósítás a kutatási és innovációs stratégiák (RIS3) keretén belül történik. A müködésre jó példát jelent a Helsinki Régió, ahol az ipar a termékfejlesztés és előállítás helyeként, a kormány a stabil interakciókat és cserét garantáló szerződéses viszonyok forrásaként, az egyetem pedig az új tudás és technológia forrásaként müködik

A Helsinki Régióban a Quadruple Helix a gondolkodás és az innováció felgyorsításának természetes eszközét jelenti. A részvételi folyamatok iránti ezen affinitás az itt kifejlesztett ökoszisztéma gondolkodási modellben világosan látható (Lappalainen és mtsai, 2015). A Quadruple Helix a polgárokat adja a keverékhez: egyrészt mint a termékek és szolgáltatások felhasználóit, másrészt mint közremüködőket és saját szakterületükön az új tudás közös teremtőit is. Az intelligens szakosodási stratégiákat vállalkozói felfedező folyamatokon keresztül, az összes ökoszisztéma-szereplővel, köztük a polgárokkal folytatott közvetlen konzultációban kell kialakítani. Ily módon a RIS3 a feltárás és felfedezés alulról felfelé irányuló folyamatává válik (Foray és mtsai, 2012; Irvin és Stansbury, 004).

A finn szakértői csoport, a müködés érdekében hat, a Hármas Spirál modell hátterében álló alapelvet dolgozott ki (Lappalainen és mtsai, 2015), amelyek mindegyike sajátos feltárási szempontot hoz a regionális innovációs ökoszisztémák összehangolásába:

1. Szereplők: Hogyan funkcionál a régióban az egyetemek, az ipar és a közigazgatás együttmüködése?

2. Struktúrák: Az együttmüködés érintkezési felületén struktúrák, hálózatok, kutatócsoportok és közös vezetés alatt álló szervezetek alakulnak ki. Mi a státuszuk?

3. Telephelyek: A fizikai, virtuális és társadalmi fejlődéshez milyen telephelyek állnak rendelkezésre?

4. Új szervezetek: Az új szereplők gyakran különböző intézményekből, például tudományos parkokból és vállalati és technológiai inkubátorokból származó elemeket integráló hibrideket képviselnek. Létrejöttek-e új szereplők a régióban? 
5. Tudás és technológia átadása és közös teremtése: Hogyan müködnek a különféle innovációs, feltalálói és szabadalmi szolgáltatások az egyetemeken és kutatóintézeteken, tudásintenzív üzleti szolgáltatásokon, az inkubátorokon és befektetői szervezeteken belül?

6. Politikai programok: Vannak-e új finanszírozási eszközök, együttmüködési támogatás, szellemi tulajdonjogra vonatkozó intézkedések és reformok, valamint adóztatás vagy szabályozás?

Az intelligens szakosodás kontextusában ez a modell már nem elegendő, ezért a Négyes Spirál kontextusában végzett munka számára egy hetedik alapelvet javaslunk:

7. Részvétel: Milyen szerepet játszik a bevont polgárok tudásbázisa és szakértelme a regionális innovációs ökoszisztéma okosabbá tételében?

Természetesen minden régiónak megvannak a maga megújulási igényei és kihívásai akkor, amikor innovációs ökoszisztémaként kifejlődik, azonban az említettekhez hasonló tényezők összetett keveréke valamennyi regionális innovációs ökoszisztéma alapját képezi. Mivel az említett intézményi szférák szerepei és feladatai változnak, a maga sajátos módján mindegyik minden korábbinál inkább koncentrál arra, hogy a polgárokat mint innovációs fejlesztőket és felhasználókat aktívan bevonja. Az utóbbi évek fejlődése rendszerszerü változásként írható le (Markkula, 2014). A RIS3 alapját képező, szélesebb értelemben vett innovációban a jelentős mértékü rugalmasság, a folyamatok adaptálása, új készségek elsajátítása, valamint a hatalom szervezetek közötti potenciális újraelosztása szükséges (Carayannis és mtsai, 2012). Ezek a kompetenciák és gondolkodásmódok elsajátíthatók, de nem szükségképpen a hagyományos egyetemek tantermeiben. Itt a cselekvés által történő tanulás és az irányított gyakorlat releváns az egyetemi tantervek új formáiként, valamint a modern egyetem különféle új fogalmai, például a „vállalkozói egyetem” (Etzkowitz és mtsai, 2012) és a ,polgári egyetem" (Goddard, 2009, 2013).

\section{Az Aalto Camp for Societal Innovation (ACSI) - az új generációs innovációs ütemterv}

A tanulmány elején is említett Aalto Camp for Societal Innovation (továbbiakban: ACSI) egy új generációs innovációs ütemterv, egyben az Aaltói Egyetemről induló globális platform. Az ACSI olyan innovációs ökoszisztémát alkot, amelyet egyidejüleg alakítanak, folyamatosan fejlesztenek, kutatnak és meghatároznak. Tevékenységként az ACSI egyesíti az oktatókat, hallgatókat és gyakorlati szakembereket, hogy mind az innovációs folyamatokkal, mind pedig a valós esetekkel megismerkedjenek, és együtt dolgozzanak a gyakorlati eredmények és hatások érdekében. A platform célja a projektek gyakorlati fenntarthatóságának megvalósítása, aminek relevanciáját az ACSI-ba bevont fenntartható és tulajdonosi szereplők végzik.

Az ACSI hálózatként működve összeköti a kutatókat és a felhasználói közösségeket, felépít egy globális, önmegújító együttmüködést, valamint rendszerekkel, gyakorlatokkal kapcsolja össze az egyetemet a környező (globális és helyi) társadalommal annak érdekében, hogy társadalmi innovációt alkothasson. Módszertanilag az ACSI a Tudásháromszög koncepción alapul, amely egyesíti az oktatást, kutatást és innovációt, hogy erősítse a megújulást és mindhárom terület hatékonyságát. Célja az egyetemi gyakorlatok hagyományos területei közötti határvonal lebontása, hatékony és inspiráló tanulási tapasztalatok, élvonalbeli kutatások globális központjának kialakításával, valamint a valós társadalmi szükségletek megoldásával. 
Az ACSI fogalma kikristályosítja a Tudásháromszög módszertani és pedagógiai lényegét, és lehetőséget biztosít arra, hogy müködési módozatát az egyetemen belül is alkalmazhassa a különböző karok és egységek közötti együttmüködésben. Ez lehetőséget nyújt egy olyan munkamódszer fokozatos megvalósításához, amely lecsökkenti a különböző belső határfelületek meglétét, és rugalmas kapcsolatokat alakít ki a társadalom többi részével. Ezáltal olyan új típusú innovációs kultúrát támogat, amely új lehetőségeket biztosít az egyetem és az egész társadalom számára. Az ACSI lándzsahegyként müködik mind a fizikai, mind a virtuális innovációs folyamatok és terek fejlesztésében. Jó és mérhető gyakorlatokat disszeminál az egyetemen belül és globálisan is a társadalomban, ugyanakkor arra is alkalmas, hogy egyetemi eszközként megvalósítsa a nemzeti és európai szintü stratégiai fejlesztési programokat.

Az ACSI 2010 óta évente szervezi meg innovációs platformját. A 2010-ben Finnországban tartott eseményen 120 szakértő vett részt Európából, Észak-Amerikából és Ázsiából. Az első rendezvény témái a Tanulás a tudástársadalomban, A közösségek stratégiai tervezése és az Új szolgáltatási koncepciók kialakítása az idősek számára címmel foglalkoztak az érintett tartalmakkal. 2011-ben szintén Helsinki adott otthont a megrendezendő nyolc napos platformnak, ahol akkor a világ 15 országából 160 résztvevő gyült össze az aktuális témák megvitatására: A munkaalapú tanulás új modelljei, Az új városi környezet kialakitása, Helyi digitális menetrend és digitális campus, Müvészet és gazdaság, Tudásháromszög: a kutatás, oktatás és innováció szinergiája. A 2012. évben (Helsinki, augusztus 7-14.) a megvitatott témák az Új típusú együttmüködések, A regionális versenyképesség és együttmüködés új modelljei, Lehetöségek az új társadalmi-gazdasági hullámban címeket viselték. A malmői Innovációs Platformot 2013. augusztus 26-29-én rendezték, az eseményt a Malmői Egyetem Szociális Innovációs Fóruma, a Skane Régió és az Aaltói Egyetem együttmüködése keretében valósították meg. A rendezvényen a Fenntartható urbánus fejlesztések téma mentén tíz megoldandó társadalmi kihívást vitattak meg. Ebben az évben 26 országból 140 meghívott résztvevő jelent meg, köztük hallgatók, szakértők, vállalkozók és közalkalmazottak, akik kisebb csoportra osztva alakították ki konkrét javaslataikat a felvetett társadalmi kihívások megoldásához. A felmerült témák:

1. Fenntartható városi fejlődés kialakítása a kultúra segítségével

2. A szén-dioxid-kibocsátás megfelezése a városi teherforgalom esetében

3. A fenntartható energia megoldásainak tesztelése

4. Új kapcsolatok és együttmüködések: a felhasználók mint szakértők a fenntartható városokban

5. A helyi innováció mint a társadalmi hatás irányítója

6. Intelligens világítás

7. Elköteleződés, folytonosság és állampolgári bizalom a városi fejlesztésekben

8. Az új helyi demokrácia megvalósítása felé

9. A város és az oktatási intézmények együttműködésének felgyorsítása

10. A regionális innovációs csomópontok összekapcsolása

A felmerült társadalmi kihívásokra megfogalmazott javaslatok innovatív jellegúek, így a hatékony müködtetésére a következő javaslatok születtek:

- A társadalmi változásokat módszeresebben integrálni kell az egyetemek kutatási, oktatási és innovációs tevékenységébe. Az egyetemen belüli és a külső világgal való együttmüködést erősíteni kell. Az egyetemi oktatásnak és a kutatásnak közelítenie kell egymáshoz. A munka hatásának növelése érdekében ezeknek kapcsolódniuk kell a valós kihívásokhoz és a társadalmi innováció tevékenységeihez.

- Növelni kell az új kutatási témák megvalósulását a folyó kutatásokban. A kutatási témák, úgy tünik, számos véletlenszerü esemény egybeesése eredményeképpen alakulnak ki, és a kutatásba csak a támogatási mechanizmusok által kerülnek be. 
A kutatási lehetőségek gyakran csak addig terjednek ki, míg egy új pályázati lehetőség adódik. A támogatási célok leszükítik a témát és befolyásolják a nézőpontokat - sok esetben minden bizonnyal a helyes irányba, viszont a jövő kutatási szükségleteit kiterjedt együttműködés és relevanciaelemzés eredményeképpen kellene meghatározni. Továbbá a támogatási lehetőségek feltérképezése jóval központosítottabbá kell váljon. Jelenleg a dolgozók munkaidejének túl nagy része fecsérlődik el az eredménytelen adminisztrációra és időigényes támogatási pályázatokra.

- A kutatás túlzott versenyközpontúságát meg kell változtatni, és a munka kultúráját kell fejleszteni. A kutatás jelenlegi versenyközpontúsága erőteljesen kapcsolódik a jelenlegi támogatási rendszerhez. A verseny megfojtja a valós párbeszédet, amely lényeges a tágabb kutatási területek megértéséhez és a jelentős jövőbeli irányok megtalálásához. A szervezeteken belül is hiányzik az együttműködés. Alapvetően ez a munkakultúrától függő kérdés, amelyet nagy kihívás gyakorolni. Stratégiai szinten már elismerték ezt a problémát, de még mindig hosszú időbe telik, míg a változás eléri a gyakorlatot, a tevékenységeket és a struktúrát.

- A kutatási terület koordinálását és összehangolását erősíteni kell. A szélesebb körü kutatási problémák megoldásához

Az oktatásnak több olyan témát kell tartalmaznia, amelyek a valós világhoz kapcsolódnak. A hallgatóknak tanulmányaik során több valós anyagot kellene fejlesztésre kinálni. A feladatokra és szakdolgozatokra mint kisegító eszközökre kell tekinteni. A munka hatása a valós világra és a munkakapcsolatok kialakítása motiváció a hallgatók számára. A végzók hallgatóknak nem csak elméleti tudással kell rendelkezniük, hanem rálátásuk kell legyen a világra és annak különbözó összefüggéseire, léptékeire. Manapság az elméleti tudás elsajátítása nagyon könynyú és költséghatékony. A jelen munkája egyre eróteljesebben a tudás alkalmazásáról, multidiszciplináris csoportokban dolgozásról és különbözó érintettekkel való együttmüködésról szól. elengedhetetlen a kutatási terület koordinációja, valamint a tudás, szakértelem és gyakorlatok többszintű terjesztése, alkalmazása és összekapcsolása, ellenkező esetben fennáll a veszélye annak, hogy a kutatási egységek közötti együttmüködés túlságosan az egyéneken múlik. Abban az esetben túl sok idő telik el a látszólagos együttmüködésen, a fenntartható hatás nélkül.

- A kutatóknak el kell kerülniük az ágazati leszükítést. A kutatás igényli a különböző ágazatok és területek mélyebb ismeretét és a valódi multidiszciplinaritást. A kutatói életpályát vonzóvá kell tenni azok számára is, akik már karriert futottak be az egyetemen kívül is, másrészről viszont az egyetem nézőpontjait terjeszteni kell az egyetemen kívüli társadalomban is. A tudást és a kutatói szükségleteket könnyebb lenne a szervezetek között átvinni, ha kialakítanánk az életpálya fejlesztésének változatosabb és rugalmasabb modelljeit.

- Az oktatásnak több olyan témát kell tartalmaznia, amelyek a valós világhoz kapcsolódnak. A hallgatóknak tanulmányaik során több valós anyagot kellene fejlesztésre kínálni. A feladatokra és szakdolgozatokra mint kisegítő eszközökre kell tekinteni. A munka hatása a valós világra és a munkakapcsolatok kialakítása motiváció a 
hallgatók számára. A végzők hallgatóknak nem csak elméleti tudással kell rendelkezniük, hanem rálátásuk kell legyen a világra és annak különböző összefüggéseire, léptékeire. Manapság az elméleti tudás elsajátítása nagyon könnyü és költséghatékony. A jelen munkája egyre erőteljesebben a tudás alkalmazásáról, multidiszciplináris csoportokban dolgozásról és különböző érintettekkel való együttmüködésről szól.

- A szakdolgozatok témáját szisztematikusabban kell meghatározni. Jelenleg a szakdolgozatok témáinak meghatározása túlságosan függ az egyénektől és a véletlen kapcsolatoktól. A szakdolgozatokat egyre inkább multidiszciplináris csoportokban kellene lebonyolítani, ahol az azonos témát több oldalról is meg lehetne vizsgálni, és ahol a kar és az egyetem stratégiai fókuszát figyelembe lehetne venni. Ezzel nagyobb hatást lehetne elérni, erősebb alapot biztosítana a doktori tanulmányokhoz és nagyobb hasznot jelentene az egyetem számára.

- A tanulásnak még inkább az együttmüködést kellene biztosítania. A tanulás folyamán a hangsúlyt egyre inkább a kísérletezésre ösztönző problémaalapú tevékenységekre kellene fordítani. A teljes kép kialakítására és az együttmüködésen alapuló tanulásra kellene fókuszálni. Sőt, a kutatási módszereket és az aktuális kutatási témákat is fel kell használni. Ez elősegítené a multidiszciplinaritás és a több területet felölelö tanulási csoportok kialakulását, valamint támogatná a hallgatói vállalkozói szellemet.

- Az innovációs rendszert és eszközeit szisztematikus egésznek kell tekinteni. Az újgenerációs innovációs tevékenységek egyre összetettebbek és nemzetköziek, és olyan kormányszerkezeten alapulnak, amelyek az önszerveződést támogatják. A jelenlegi innovációs rendszer alapstruktúrája általában a projekt. Amint a projekteknek vége, különösen a félig kész eredményeknek nehéz dolguk van, amikor a folyamatos fejlesztés és gyakorlatba ültetés csatornáit keresik. Az önálló projektek végzetével eltünik az innovációs tevékenységek platformja: a csatornák, a kapcsolatok és a közösségek, amelyek fejleszthetnék és alkalmazhatnák az eredményeket. A kísérletezés és a gyors prototípuskészítés helyett az innovációs tevékenységek megtorpannak és az eredmények elvesznek. A társadalmi innovációs tevékenységekre is tekinthetünk úgy, mint immateriális tőkébe való rendszerszerü befektetésekre. Ez kihangsúlyozza az egyetem mint az innovációs rendszer központi szereplőjének szerepét.

Finnországban az Aalto társadalmi innovációs tanulmányok címmel meghirdetett kurzus keretében a hallgatók részt vesznek az ACSI valós eseteket előkészítő folyamatában. A részvétel más formái is léteznek, mint például az ACSI-hoz kapcsolódó elökészítő workshopok, ahol a témák konkretizálódása után a hallgatók esettanulmányokat készítenek és összekapcsolják azt saját tanulmányaikkal. A hallgatók részt vesznek a táborban, tovább finomítják az anyagot, és akár a szakdolgozatukat is elkészíthetik az ezen a munkán alapuló esetről. Az elkészített feladatokat és szakdolgozatokat a kutatás bevezető állomásaiként használják, melyet folyamatként lehet irányítani, valahányszor kutatási kérdések merülnek fel.

A meghirdetett kurzusokon és workshopokon a tanulás problémaalapú együttmüködésen nyugszik, több teret enged a kreatív gondolkodásnak és az innovatív oktatási megoldásoknak, mint a hagyományos módszerek. A magas minőségű kutatási célokat rugalmasabban hozzá lehet kapcsolni a kutatásokhoz, mint korábban, mert a jelentős társadalmi kihívások meghatározása megalapozza azt a tudást, amely szükséges egy adott témában megvalósítandó, mélyreható és több területet felölelö kutatás szükségességének elemzéséhez. Egy ACSI kurzus megszervezése részben a Tudásháromszög koncepciójának megvalósítása és fejlesztése. A változó tartalmú kurzusok megtervezése (különösen a $\mathrm{PhD}$ hallgatók részére) rugalmasságot visz a rendszerekbe, és együttmüködéseket alakítanak ki a különböző területek alap-, posztgraduális és továbbképzésében részt vevő hallgatói között. 


\section{Együttesen teremtő tudás - A régió tudással való megtöltése}

A globalizáció és digitalizáció korszakában Európa hatalmas társadalmi kihívásokkal szembesül. A piac erői önmagukban nem képesek ezeket a kihívásokat megfelelően kezelni, sőt sok esetben inkább elmélyítik a társadalmi problémákat. Valamennyi társadalmi szereplőt bevonó, együttműködő, együttesen teremtő megközelítésre van szükség az olyan regionális politika megvalósításához, amely az adott régióban a növekedés, a verseny és az életminőség javításához új lehetőségeket teremt. A leírt megközelítés új lehetőségeket ad arra is, hogy az egyetemeket mint a problémák újragondolásában és a megoldások keresésében közremüködő intézményeket a munkába bevonhassuk. A RIS3, a Helsinki Régióban alkalmazott formában, fontos mozgatóerő lehet ebben az erőfeszítésben.

Mind az Európai Bizottság hivatalos dokumentumai, mind az ACSI tapasztalatai kiemelik a társadalmi tőke fontosságát a régiók megújulásában. Az Európai Unió intelligens szakosodási programjának célja az említett kihívásnak való megfelelés. A Hármas Spirál modell korszerüsítése és az ökoszisztéma-központú gondolkodás intézményesítése során az élenjáró régiók a társadalmi kihívásokat jobban képesek kezelni, a tudományos kiválóságokat és az ipari vezetést fel tudják használni a fontos problémák kezelésére. Az iparból, az egyetemekről és a közszférából származó kockázatviselöknek a közös értékteremtési munkafolyamatokba való közvetlen bevonása, valamint az állampolgárok aktív részvételének elősegítése, ezekben való alkalmazása az intelligens régiók sikerének előfeltétele, s a kulcsa annak, hogy a regionális potenciált jobb életminőséggé változtathassuk át. A potenciálnak gyakorlattá való aktív átalakításában betöltött szerepük révén az egyetemek alapvető szerepet játszanak abban, hogy a régiót tudással töltsék meg.

\section{Összefoglalás}

Az egyetemek akkor tudnak sikeresen bekapcsolódni a regionális üzleti életbe és a közösségbe, ha hatékonyan segítik a helyi innovációs képesség kialakítását is. Ez különösen fontos a hátrányos helyzetü régiókban, ahol a sikeres fejlödés elengedhetetlen előfeltétele az innovációs kapacitás kialakítása és növelése. A prosperáló régiókban is alapvető feladat az innovációs kapacitás folyamatos erősítése. A tudás létrehozása, aktív terjesztése és felhasználása alapvetően fontos a régiók intelligens jellegének megteremtéséhez és megörzéséhez. A közös tanulás az ökoszisztémán belüli együttmüködés sarkköve. Ahogyan a Helsinki Régió példája mutatja, az egyetemeknek kulcsszerepük van a régiók intelligensebbé tételében és a folyamatos fejlődés elősegítésében.

A vonzó munka- és lakóhelyek kialakítása fontos a prosperálást segítő regionális innovációs platformok kialakításához. Az egyetemek segíteni tudják a régiókban a társadalomdinamikai modellek hatékony felhasználását fejlesztési folyamataik és társadalmi szolgáltatásaik javítása érdekében. Az egyetemek kutatási és innovációs bázisa a regionális innovációs ökoszisztéma kulcseleme. Az utóbbi meghatározó módon segítheti a térségi szereplőket a közös jövőkép kialakításában, az igényelt szolgáltatások gyakorlati megvalósításában és a termékek elöállításában.

Az Aaltói Egyetem koordinálásával közel tíz éve elindított, a társadalmi problémákra koncentráló projektek célja a hatékony és fenntartható gyakorlati megoldások kialakítása. Ehhez az egyetemi kultúra átalakulására is szükség van, ami segíti a térségi szereplök felelősségének újszerü megközelítését és szorosabb együttmüködését, a régiós feladatok hatékony megoldását. E tendenciákra épít az EU 2021-2028 közötti időszakra szóló költségvetése is, amely a források elosztásánál a mai tervek szerint minden területen támogatja majd a rendszerszintü innovációt. 


\section{Irodalom}

Carayannis, E., Barth, T., \& Campbell, D. (2012). The Quintuple Helix Innovation Model: Global Warming as a Challenge and Driver for Innovation. Journal of Innovation and Entrepreneurship, 1(2), 1-12. DOI: $10.1186 / 2192-5372-1-2$

CoR (Committee of the Regions) (2013). Opinion of the Committee of the Regions on "Closing the Innovation Divide". Official Journal of the European Union, 56(C218). 12-21.

CESAER Smart Initiative (CSI) (2011). Report of the workshop on Financial Sustainability March 10th 11th, 2011, Vienna.

EKA (Project Helsinki as Forerunner Area) (2014). Helsinki Smart Region: Pioneering for Europe 2020. Helsinki: EKA B Project/Helsinki-Uusimaa Regional Council.

Etzkowitz, H. \& Ranga, M. (2011). Spaces: A Triple Helix Governance Strategy for Regional Innovation. In Rickne, A; Laestadius, S. \& Etzkowitz, H. (szerk.), Regional Innovation Systems: The Swedish Experience of Policy, Governance and Knowledge Dynamics. London: Routledge.

Etzkowitz, H., Ranga, M. \& Dzisah, J. (2012). Wither the University? The Novum Trivium and the Transition from Industrial to Knowledge Society. Social Science Information, 51(2), 143-164. DOI: 10.1177/0539018412437099

EUA Charta (2008): European Universities' Charter on Lifelong Learning. European University Association, Belgium. 14.

EUA (European University Association) (2014). The Role of Universities in Smart Specialisation Strategies. Brussels: EUA Publications.

Európai Bizottság (2017): Unióbeli innováció: bizonyos elörelépés megfigyelhető, azonban kiegyenlítettebb fejlödésre van szükség. Sajtóközlemény, http:// europa.eu/rapid/press-release_IP-17-1673 hu.htm

Foray, D., Goddard, J., Beldarrain, X. G., Landabaso, M., McCann, P., Morgan, K., Nauwelaers, C. \& Ortega-Argiles, R. (2012). Guide to Research and Innovation Strategies for Smart Specialisation (RIS 3). Brussels: European Commission Smart Specialisation Platform.

Goddard, J. (2009). Re-Inventing the Civic University. London: Nesta.

Goddard, J. (2011). Connecting Universities to Regional Growth: A Practical Guide. Brussels: European Commission Smart Specialisation Platform.

Helsinki-Uusimaa Regional Council (2014). Smart Specialisation in the Helsinki-Uusimaa Region: Research and Innovation Strategy for Regional Development 2014-2020. Helsinki: Helsinki-Uusimaa Regional Council.
Hervas, F., Mulatero, F. (2009). Knowledge Policy in the EU: From the Lisbon Strategy to Europe 2020. DOI: $10.1007 / \mathrm{s} 13132-010-0020-9$

https://www.researchgate.net/publication/226488410 Knowledge Policy in the EU From the Lisbon Strategy_to_Europe_2020 Utolsó letöltés: 2019.03.08.

Irvin, R. \& Stansbury, J. (2004). Citizen Participation in Decision Making: Is it Worth the Effort? Public Administration Review, 64(1), 55-64. DOI: 10.1111/j.1540-6210.2004.00346.x

Kálmán Anikó (2014). A Tudásháromszög, az egyetemi kultúra megújítója. In Mészáros Attila (szerk.), A felsőoktatás tudományos, módszertani és munkaerőpiaci kihívásai a XXI. században. Győr: Széchenyi István Egyetem. 244-258.

Kálmán, A., Farkas, L. \& Dékány, D. (2015). Developing a Student Innovation Ecosystem. In Lappalainen, P., Markku Markkula, M., \& Kune, H. (szerk.), Orchestrating Regional Innovation Ecosystems: Espoo Innovation Garden. Espoo: Aalto University, Laurea University of Applied Sciences, Built Environment RYM Oy. 241-254

Lappalainen, P. \& Markkula, M. (2013, szerk). The Knowledge Triangle. Re-Inventing the Future. Finland: Multiprint Oy.

Lappalainen, P., Markkula, M. \& Kune, H. (2015, Eds.). Orchestrating Regional Innovation Ecosystems: Espoo Innovation Garden. Espoo: Aalto University in cooperation with Laurea University of Applied Sciences and Built Environment Innovations RYM Ltd.

Launonen, M. \& Viitanen, J. (2011). Hubconcepts. Global Best Practice for Managing Innovation Ecosystems and Hubs. Helsinki: Hubconcepts Inc.

Markkula, M. \& Kune, H. (2013). Horizon 2020: Regional Innovation Ecosystems: from theory to practice. In European Commission, Open Innovation 2013. 87-101.

Markkula, M. \& Kune, H. (2015). Making Smart Regions Smarter: Smart Specialization and the Role of Universities in Regional Innovation Ecosystems. Technology Innovation Management Review. 5(10), 7-15. DOI: 10.22215/timreview/932

Markkula, M. (2011). Trends and Country Reports: Aalto University - The Forerunner of European University Reform to Increase Societal Impact. In: European Comission: Service Innovation Yearbook 2010-2011. European Comission, Belgium. 46-57.

Markkula, M. (2013). The Knowledge Triangle Renewing the University Culture. In Lappalainen, P. \& Markkula, M. (szerk.), The Knowledge Triangle: Re-Inventing the Future. Finland: European Society for Engineering Education (SEFI), Aalto University, Universitat Politecnica de Valencia. 11-31. 
Markkula, M. (2014). Renewing the Triple Helix in a Context of Smart Specialisation. https://www. triplehelixassociation.org/helice/volume-3-2014/helice-issue-1/renewing-triple-helix-context-smart-specialisation Utolsó letöltés: 2019. 03. 04.
NESTA (2015). Pushing boundaries: the 2015 UK alternative finance industry report. https://www. nesta.org.uk/report/pushing-boundaries-the-2015-ukalternative-finance-industry-report/ Utolsó letöltés: 2019. 03. 08 .

Wallin, J. (2012, szerk.). Eco Urban Living. Espoo as an Innovation Hub in 2020. Espoo: Redfina Oy.

\section{Absztrakt}

Napjaink „okos régiói” képesek hatékony innovációs ökoszisztémát létrehozni a térségi szereplők sokféle tudás-, emberi, strukturális és kapcsolati - tőkéjét összekapcsolva. Az egyetemek cselekvő közreműködése alapvető fontosságú a regionális erösségek és kapacitások azonosításában és kiaknázásában - összhangban az intelligens szakosodást támogató kutatási és innovációs stratégiák európai programjával. A regionális felsőoktatási intézmények működésében meghatározó jelentőségű a fenntartható fejlődés új generációs koncepciója, ami egyúttal fontos eszköze is „,a tudás „körkörös gazdasága” fogalmának megismertetésében és megvalósításában. A koncepció megvalósítását támogatja, hogy a nemzeti és európai finanszírozó szervek újra megvizsgálják és tanulmányozzák a már befejezett projektek eredményeit, segítve a releváns eredmények ismételt felhasználását új regionális és nemzeti kontextusban. Így a kutatási programok és a befejezett projektek eredményei (ötletek, ajánlások, módszerek, gyakorlati javaslatok, prototípusok és találmányok) újra alkalmazhatók a jelenleg futó és a későbbi programokban és projektekben is. Ez erősítheti a vállalkozói egyetemek és az azokkal együttmüködő kormányzati szervek együttmüködését a társadalmi innováció regionális és európai katalizálásában is. Az Aalto Egyetem és a Párizsi Új Klub által 2010-2014-ben kifejlesztett Aalto Camp for Societal Innovation (ACSI) a társadalmi innováció fontos platformja. Ez a globális hálózatokat egyesítő platform a kutatás, a tanulás és a gyors prototípuskészítés egyidejü elősegítésével hozzájárul a valós társadalmi kihívások kapcsán felmerülő szükségletek innovatív kielégítéséhez és a kapcsolódó rendszerszintü változásokhoz. Az ACSI keretében a különböző karok és egységek közötti együttmüködésben az egyetemen belül is alkalmazzák a Tudásháromszög modellt, ami lehetővé teszi módszertani és pedagógiai alapvetéseinek továbbfejlesztését is a gyakorlati alkalmazás tapasztalatainak figyelembe vételével. 